\title{
INSECTICIDAL JOINT ACTION OF TERNARY EXTRACT MIXTURES OF FOUR SPECIES OF TROPICAL PLANTS AGAINST Plutella xylostella AND Crocidolomia pavonana
}

\author{
Djoko Prijono, Maya Anggraini, Sri Riski Maryani, \& Elina Diana Surya \\ Department of Plant Protection, Faculty of Agriculture, Bogor Agricultural University, Indonesia \\ Jl. Kamper Kampus IPB Dramaga Bogor 16680 \\ E-mail: djokopr@apps.ipb.ac.id
}

Manuscript received: 16 November 2020. Revision accepted: 10 January 2020.

\begin{abstract}
Insecticidal joint action of ternary extract mixtures of four species of tropical plants against Plutella xylostella and Crocidolomia pavonana. The diamondback moth (DBM), Plutella xylostella, and the cabbage head caterpillar (CHC), Crocidolomia pavonana, were two main pests of cruciferous vegetable crops. Among the viable alternative ingredients that could be utilized to control those two pests were eco-friendly botanical insecticides. This study was conducted to evaluate the joint action of ternary extract mixtures of four tropical plant species, i.e. Piper aduncum (Pa), Piper retrofractum (Pr), Sapindus rarak (Sr), and Tephrosia vogelii (Tv), against DBM and CHC. Results of leaf-residue feeding bioassays showed that based on co-toxicity ratio at both $\mathrm{LC}_{50}$ and $\mathrm{LC}_{95}$ levels, ternary mixtures of $\mathrm{Pa}$ extract with $\mathrm{Sr}$ and Tv extracts at concentration ratios of 1:5:1, 1:5:2, and 2:5:1 indicated synergistic joint action on DBM larvae. A mixture of $\mathrm{Pa}, \mathrm{Sr}$ and Tv extracts at a ratio of 2:5:1 was also synergistic to $\mathrm{CHC}$ at both $\mathrm{LC}_{50}$ and $\mathrm{LC}_{95}$ levels. This mixture at the 1:5:1 ratio was synergistic on $\mathrm{CHC}$ at the $\mathrm{LC}_{50}$ level but antagonistic at the $\mathrm{LC}_{95}$ level whereas at the 1:5:2 ratio was antagonistic to $\mathrm{CHC}$ at both $\mathrm{LC}_{50}$ and $\mathrm{LC}_{95}$ levels. Furthermore, ternary mixtures of Pr extract with $\mathrm{Sr}$ and $\mathrm{Tv}$ extracts at the three concentration ratios were synergistic to $\mathrm{CHC}$. Thus, ternary mixtures of $\mathrm{Pa}$ or $\mathrm{Pr}$ extract with $\mathrm{Sr}$ and $\mathrm{Tv}$ extracts at appropriate concentration ratios are potential alternatives for the control of DBM and CHC.
\end{abstract}

Key words: botanical insecticides, cabbage pests, joint action, ternary mixtures, tropical plants

\section{INTRODUCTION}

The diamondback moth (DBM), Plutella xylostella (L.) (Lepidoptera: Plutellidae), and the cabbage head caterpillar (CHC), Crocidolomia pavonana (F.) (Lepidoptera: Crambidae), were two major pests of cruciferous vegetable crops (Sastrosiswojo \& Setiawati, 1993; Durairaj et al., 2016). Normally DBM could be adequately suppressed by its natural enemies complex when chemical control was not intensively undertaken (Sastrosiswojo \& Sastrodihardjo, 1986; Sarfraz et al., 2005; Furlong et al., 2013; Philips et al., 2014), but CHC had no effective natural enemies (Sastrosiswojo \& Setiawati, 1992). Consequently, crucifer growers in Indonesia often use older, broad-spectrum and toxic insecticides to control crucifer pests, especially against $\mathrm{CHC}$, due to limited knowledge of farmers on effective non-chemical control methods (Sastrosiswojo \& Setiawati, 1992; Rauf et al., 2004; Shepard et al., 2009; Grzywacz et al., 2010). Intensive use of chemical insecticides on crucifers would badly interfere with the activity of pest natural enemies and impede the implementation of crucifer integrated pest management (Shepard et al., 2009). In addition, intensive use of synthetic insecticides could cause various undesirable side effects including pest resistance and resurgence, killing of non-target organisms including pest natural enemies, food web contamination, residue hazards, and health risks to pesticide applicators (Aktar et al., 2009; Wyckhuys et al., 2020). Thus, it was necessary to develop alternative control agents that are effective against crucifer pests but relatively safe for non-target organisms including pest natural enemies. In this regard, botanical insecticides are worthwhile to be evaluated.

Extracts of three plant species, i.e. spiked pepper (Piper aduncum), Javanese long pepper (Piper retrofractum), and fish-poison bean (Tephrosia vogelii), were reported possessing strong insecticidal activity against DBM and CHC (Zarkani et al., 2009; Zarkani et al., 2010; Chenta \& Prijono, 2014; Nailufar \& Prijono, 2017). In addition, soapberry (Sapindus rarak) extract was reported exhibiting moderate insecticidal activity against CHC (Syahroni \& Prijono, 
2013; Mediana \& Prijono, 2014). One of the attempts to enhance the insecticidal activity of botanical insecticides is by using mixed plant extracts. Binary mixtures of $P$. aduncum and $T$. vogelii as well as $P$. retrofractum and $T$. vogelii extracts were reported to have strong and synergistic insecticidal activity against CHC (Nurfajrina \& Prijono, 2015; Nailufar \& Prijono, 2017), while those of $P$. aduncum and $S$. rarak (Syahroni \& Prijono, 2013) as well as T. vogelii and $S$. rarak (Irawan, 2012) had moderate but synergistic insecticidal activity against $\mathrm{CHC}$.

This study was conducted to assess joint action of ternary extract mixtures containing P. aduncum, $S$. rarak and $T$. vogelii extracts at concentration ratios of 1:5:1, 1:5:2, and 2:5:1 against DBM and CHC. The other ternary extract mixtures containing $P$. retrofractum, $S$. rarak and $T$. vogelii extracts at the same concentration ratios were tested against $\mathrm{CHC}$ only.

\section{MATERIALS AND METHODS}

Research Site. This study was conducted at the Laboratory of Insect Physiology and Toxicology, Department of Plant Protection, Bogor Agricultural University, Bogor, Indonesia, from September 2018 to July 2019.

Procurement of Insecticidal Plants. Spiked pepper ( $P$. aduncum) fruits, were taken from bushes at Dramaga campus of Bogor Agricultural University, Javanese long pepper ( $P$. retrofractum) fruits were obtained from the Spice and Medicinal Plants Research Institute in Bogor; fish-poison bean (T. vogelii) leaves were procured from Bina Sarana Bakti organic farm at Cisarua District, Bogor Regency and soapberry (S. rarak) fruits were purchased from a local market in Bogor, West Java, Indonesia. Spiked pepper fruits, Javanese long pepper fruits and fish-poison bean leaves were cut to small pieces and air-dried for one week in the laboratory before extraction. Soapberry fruits were directly sliced prior to extraction.

Cultivation of Broccoli Plants. Pesticide-free broccoli leaves were used for feeding the test insects and as treatment substrates. Those leaves were taken from potted broccoli 'Super Royal Green' of at least 2 months after sowing. Broccoli plants were cultivated following Abizar \& Prijono (2010).

Rearing of Test Insects. DBM and CHC used as the test insects in this study were offsprings of DBM and $\mathrm{CHC}$ adults collected from the teaching farm of the
Faculty of Agriculture, Bogor Agricultural University at Pacet District, Cianjur Regency, West Java (S 646'6.7', E 107²'57.6", $1100 \mathrm{~m}$ asl). DBM and $\mathrm{CHC}$ were reared in the laboratory according to the method described by Prijono et al. (2019) and Prijono \& Hassan (1992), respectively. Briefly, DBM larvae and $\mathrm{CHC}$ were fed pesticide-free broccoli leaves and their adults were fed $10 \%$ honey solution in a cotton swab.

Extraction of Plant Materials. Extraction of four test plant materials was done using immersion method (Houghton \& Raman, 1998). Cut pieces of spiked pepper fruits, Javanese long pepper fruits and fish-poison bean leaves were extracted with ethyl acetate (Nurfajrina \& Prijono, 2015) and slices of soapberry fruits were extracted with methanol (Syahroni \& Prijono, 2013). Solvent in the extracts was evaporated to dryness using a rotary evaporator, then all extracts obtained were kept in refrigerator $\left(\mathrm{ca} .4{ }^{\circ} \mathrm{C}\right)$ until used for bioassays.

Method of Toxicity Testing. Extracts of four plant species were tested singly and as ternary mixtures against DBM and CHC using a leaf-residue feeding method. Each extract was tested at five concentration levels that were expected to give insect mortality between $15 \%$ and $95 \%$ as determined in preliminary tests. Each test extract was mixed thoroughly with methanol (solvent) and Tween 80 (emulsifier) and then diluted with distilled water to the desired volume. Final concentrations of methanol and Tween 80 in each extract dilution were $1 \%$ and $0.2 \%$, respectively. Distilled water containing $1 \%$ methanol and $0.2 \%$ Tween 80 was used as a control solution.

Bioassays procedures against DBM followed Prijono et al. (2019) and those against CHC followed Nailufar \& Prijono (2017). Fifty third-instar DBM larvae and 60 second-instar $\mathrm{CHC}$, in groups of 10 each, were used for each concentration level and control. Test larvae were fed treated broccoli leaves for $72 \mathrm{~h}$ and then kept on untreated leaves for an additional $24 \mathrm{~h}$. The number of dead larvae was counted daily until $96 \mathrm{~h}$ after treatment (HAT) and cumulative larval mortality data at 96 HAT were analyzed with probit method using PoloPlus (Robertson et al., 2003).

Mixtures of spiked pepper, fish-poison bean and soapberry extracts were tested against DBM and CHC at three concentration ratios, i.e. 1:5:1, 2:5:1, and 1:5:2 $(\mathrm{w} / \mathrm{w})$. Mixed extracts of Javanese long pepper, fishpoison bean and soapberry at the same concentration ratios were tested against $\mathrm{CHC}$ only. Each extract mixture was tested at five and six concentration levels 
against $\mathrm{DBM}$ and $\mathrm{CHC}$, respectively, which were expected to give mortality of test insects between $15 \%$ and $95 \%$. Ternary extract mixtures were prepared by mixing suspension of the three component extracts at appropriate proportions. The method of treatment and observation in mixed extract tests were the same as in the single extract tests. Cumulative larval mortality data were analyzed with probit method as in the single extract tests.

The type of joint action of each ternary extract mixture was determined based on independent action hypothesis by calculating co-toxicity ratio at $\mathrm{LC}_{\mathrm{x}}$ level $(\mathrm{x}=50$ or 95$)$. The co-toxicity ratio $(\mathrm{CTR})$ at the $\mathrm{LC}_{\mathrm{x}}$ level was calculated as follows (Robertson \& Smith, 1984):

$$
\mathrm{CTR}=\text { Expected } \mathrm{LC}_{\mathrm{x}} \div \text { Observed } \mathrm{LC}_{\mathrm{x}}
$$

where observed $\mathrm{LC}_{\mathrm{x}}$ was obtained from the result of probit analysis while expected $\mathrm{LC}_{\mathrm{x}}$ was calculated based on the following estimation (extended from Robertson \& Smith, 1984):

$\mathrm{P}_{\mathrm{E}}=\mathrm{m}+\left\{(1-\mathrm{m})\left[\mathrm{P}_{1}+\left(1-\mathrm{P}_{1}\right) \mathrm{P}_{2}+\left(1-\mathrm{P}_{1}\right) \mathrm{P}_{3}-\left(1-\mathrm{P}_{1}\right) \mathrm{P}_{2} \mathrm{P}_{3}\right]\right\}$

where $\mathrm{P}_{\mathrm{E}}$ was the expected proportional mortality due to $\mathrm{LC}_{\mathrm{x}}, \mathrm{m}$ is the proportional mortality in the control group, and $\mathrm{P}_{1}, \mathrm{P}_{2}$, and $\mathrm{P}_{3}$ were the predicted proportional mortality due to concentration of extract 1 , extract 2 , and extract 3 in the mixture, respectively, and estimated from the probit regression lines for extract 1 , extract 2 , and extract 3 separately.

The type of joint action of the test extract mixtures was categorized as follows (the reciprocal of combination index described by Chou \& Talalay [1984]): (1) if CTR $>1.0$, then synergistic joint action was indicated; (2) if CTR $=1.0$, then the mixture exhibited additive joint action; (3) if CTR $<1.0$, then the mixture had an antagonistic joint action.

\section{RESULTS AND DISCUSSION}

Based on the comparison of $\mathrm{LC}_{50}$ of single extracts against DBM, spiked pepper $(\mathrm{Pa})$ extract was about 1.45 and 9.9 times more toxic than fish-poison bean (Tv) and soapberry (Sr) extract, respectively (Table 1). The spiked pepper extract was about as toxic as $T v$ extract against $\mathrm{CHC}$ while $\mathrm{Sr}$ extract was about 9.7 and 10.4 times less toxic than $\mathrm{Pa}$ and $\mathrm{Tv}$ extract, respectively (Table 2). In another set of bioassays, fishpoison bean extract was about 2.6 and 23.1 times more toxic than Javanese long pepper (Pr) and $\mathrm{Sr}$ extract, respectively, against $\mathrm{CHC}$ (Table 3 ).

Mixed extracts of $\mathrm{Pa}, \mathrm{Sr}$ and $\mathrm{Tv}$ at the three concentration ratios (1:5:1, 1:5:2, and 2:5:1) exhibited synergistic joint action against DBM at both $\mathrm{LC}_{50}$ and $\mathrm{LC}_{95}$ levels (Table 4). On the other hand, only at the concentration ratio of 2:5:1 that the extract mixture of $\mathrm{Pa}, \mathrm{Sr}$ and $\mathrm{Tv}$ was synergistic against $\mathrm{CHC}$ at both $\mathrm{LC}_{50}$ and $\mathrm{LC}_{95}$ levels. This mixture at the 1:5:1 ratio was synergistic on $\mathrm{CHC}$ at the $\mathrm{LC}_{50}$ level but antagonistic at the $\mathrm{LC}_{95}$ level whereas at the 1:5:2 ratio was antagonistic to $\mathrm{CHC}$ at both $\mathrm{LC}_{50}$ and $\mathrm{LC}_{95}$ levels (Table 4). Furthermore, mixed extracts of $\mathrm{Pr}, \mathrm{Sr}$ and $\mathrm{TV}$ at the three concentration ratios $(1: 5: 1,1: 5: 2$, and $2: 5: 1)$ were synergistic against $\mathrm{CHC}$ at both $\mathrm{LC}_{50}$ and $\mathrm{LC}_{95}$ levels (Table 5).

The results of this study showed that $\mathrm{LC}_{95}$ of $\mathrm{Pa}$ and Tv extract was less than $0.5 \%$ indicating that these extracts had strong insecticidal activity against DBM. On the other hand, Sr extract exhibited rather weak

Table 1. Toxicity of single and mixed extracts of P. aduncum, S. rarak, and T. vogelii on P. xylostella larvae at $96 \mathrm{~h}$ after treatment

\begin{tabular}{lcccc}
\hline Type of extracts & $b \pm \mathrm{SE}^{\mathrm{a}}$ & $\mathrm{LC}_{50}(95 \% \mathrm{FL})^{\mathrm{b}}(\%)$ & $\mathrm{LC}_{95}(95 \% \mathrm{FL})^{\mathrm{b}}(\%)$ & $\chi^{2}$ goodness-of-fit $^{\mathrm{c}}$ \\
\hline \multicolumn{5}{c}{ Single extracts } \\
\hline P. aduncum $(\mathrm{Pa})$ & $11.06 \pm 1.41$ & $0.142(0.128-0.158)$ & $0.200(0.174-0.287)$ & $4.407^{\mathrm{ns}}$ \\
S. rarak $(\mathrm{Sr})$ & $4.90 \pm 0.68$ & $1.406(1.245-1.539)$ & $3.045(2.627-3.880)$ & $1.425^{\mathrm{ns}}$ \\
T. vogelii $(\mathrm{Tv})$ & $5.60 \pm 0.60$ & $0.206(0.145-0.312)$ & $0.404(0.281-2.322)$ & $12.744 * *$ \\
\hline \multicolumn{5}{c}{ Mixed extracts, Pa:Sr:Tv } \\
\hline $1: 5: 1$ & $5.62 \pm 0.61$ & $0.494(0.417-0.601)$ & $0.969(0.745-1.802)$ & $4.987^{\mathrm{ns}}$ \\
$1: 5: 2$ & $6.16 \pm 0.83$ & $0.360(0.325-0.390)$ & $0.666(0.591-0.804)$ & $2.944^{\mathrm{ns}}$ \\
$2: 5: 1$ & $9.18 \pm 1.41$ & $0.314(0.286-0.335)$ & $0.474(0.434-0.549)$ & $2.230^{\mathrm{ns}}$ \\
\hline
\end{tabular}

a $b=$ slope of the probit regression line, $\mathrm{SE}=$ standard error. ${ }^{\mathrm{b}} \mathrm{FL}=$ fiducial limit. ${ }^{\mathrm{c} * *}$ : statistically significant at 0.01 level; ns = not significant. 
Table 2. Toxicity of single and mixed extracts of $P$. aduncum, S. rarak, and $T$. vogelii on $C$. pavonana larvae at $96 \mathrm{~h}$ after treatment

\begin{tabular}{|c|c|c|c|c|}
\hline Type of extracts & $b \pm \mathrm{SE}^{\mathrm{a}}$ & $\mathrm{LC}_{50}(95 \% \mathrm{FL})^{\mathrm{b}}(\%)$ & $\mathrm{LC}_{95}(95 \% \mathrm{FL})^{\mathrm{b}}(\%)$ & $\chi^{2}$ goodness-of-fit ${ }^{\mathrm{c}}$ \\
\hline \multicolumn{5}{|c|}{ Single extracts } \\
\hline P. $\operatorname{aduncum}(\mathrm{Pa})$ & $25.18 \pm 5.42$ & $0.098(0.090-0.102)$ & $0.114(0.111-0.119)$ & $2.206^{\mathrm{ns}}$ \\
\hline S. $\operatorname{rarak}(\mathrm{Sr})$ & $4.49 \pm 0.87$ & $0.955(0.376-1.214)$ & $2.219(1.800-4.624)$ & $3.318^{\mathrm{ns}}$ \\
\hline T. vogelii $(\mathrm{Tv})$ & $3.48 \pm 0.77$ & $0.092(0.050-0.118)$ & $0.273(0.232-0.377)$ & $1.519^{\mathrm{ns}}$ \\
\hline \multicolumn{5}{|c|}{ Mixed extracts, Pa:Sr:Tv } \\
\hline $1: 5: 1$ & $3.28 \pm 0.48$ & $0.510(0.333-0.633)$ & $1.618(1.199-3.364)$ & $3.220^{\mathrm{ns}}$ \\
\hline $1: 5: 2$ & $2.64 \pm 0.47$ & $0.424(0.280-0.530)$ & $1.779(1.405-2.769)$ & $0.175^{\mathrm{ns}}$ \\
\hline $2: 5: 1$ & $3.23 \pm 0.60$ & $0.050(0.033-0.061)$ & $0.161(0.133-0.226)$ & $0.726^{\mathrm{ns}}$ \\
\hline
\end{tabular}

${ }^{\mathrm{a}} b=$ slope of the probit regression line, $\mathrm{SE}=$ standard error. ${ }^{\mathrm{b}} \mathrm{FL}=$ fiducial limit. ${ }^{\mathrm{c}} \mathrm{ns}=$ statistically not significant.

Table 3. Toxicity of single and mixed extracts of P. retrofractum, $S$. rarak, and $T$. vogelii on $C$. pavonana larvae at $96 \mathrm{~h}$ after treatment

\begin{tabular}{ccccc}
\hline Type of extracts & $b \pm \mathrm{SE}^{\mathrm{a}}$ & $\mathrm{LC}_{50}(95 \% \mathrm{FL})^{\mathrm{b}}(\%)$ & $\mathrm{LC}_{95}(95 \% \mathrm{FL})^{\mathrm{b}}(\%)$ & $\chi^{2}$ goodness-of-fit $^{\mathrm{c}}$ \\
\hline \multicolumn{5}{c}{ Single extracts } \\
\hline P. retrofractum $(\mathrm{Pr})$ & $5.98 \pm 0.61$ & $0.160(0.117-0.225)$ & $0.301(0.217-1.393)$ & $13.478^{* *}$ \\
S. rarak (Sr) & $5.13 \pm 0.65$ & $1.412(1.099-1.642)$ & $2.956(2.326-5.793)$ & $4.832^{\mathrm{ns}}$ \\
T. vogelii (Tv) & $2.86 \pm 0.48$ & $0.061(0.024-0.084)$ & $0.229(0.165-0.606)$ & $3.424^{\mathrm{ns}}$ \\
\hline \multicolumn{5}{c}{ Mixed extracts, Pa:Sr:Tv } \\
\hline $1: 5: 1$ & $2.51 \pm 0.30$ & $0.219(0.109-0.371)$ & $0.991(0.504-30.41)$ & $9.967^{*}$ \\
$1: 5: 2$ & $3.87 \pm 0.47$ & $0.171(0.149-0.191)$ & $0.455(0.380-0.596)$ & $1.330^{\mathrm{ns}}$ \\
$2: 5: 1$ & $3.72 \pm 0.41$ & $0.217(0.193-0.242)$ & $0.600(0.495-0.796)$ & $1.273^{\mathrm{ns}}$ \\
\hline
\end{tabular}

${ }^{a} b=$ slope of the probit regression line, $\mathrm{SE}=$ standard error. ${ }^{\mathrm{b}} \mathrm{FL}=$ fiducial limit. ${ }^{\mathrm{c}}$ Statistically significant at $0.05\left({ }^{*}\right)$ or $0.01(* *)$ level; ns = not significant.

Table 4. Joint effect of $P$. aduncum (Pa), S. rarak (Sr), and T. vogelii (Tv) extract mixtures on P. xylostella and C. pavonana larvae at $96 \mathrm{~h}$ after treatment

\begin{tabular}{ccccc}
\hline $\begin{array}{c}\text { Concentration ratio of } \\
\mathrm{Pa}, \mathrm{Sr} \text { and Tv extract }\end{array}$ & $\begin{array}{c}\text { Expected } \mathrm{LC}_{50}{ }^{\mathrm{a}} \\
(\%)\end{array}$ & $\begin{array}{c}\text { Co-toxicity } \\
\text { ratio at } \mathrm{LC}_{50}{ }^{\mathrm{a}}\end{array}$ & $\begin{array}{c}\text { Expected } \\
\mathrm{LC}_{95}{ }^{\mathrm{a}}(\%)\end{array}$ & $\begin{array}{c}\text { Co-toxicity } \\
\text { ratio at } \mathrm{LC}_{95}{ }^{\mathrm{a}}\end{array}$ \\
\hline $1: 5: 1$ & 0.933 & 1.89 & 1.295 & 1.34 \\
$1: 5: 2$ & 0.797 & 2.21 & 1.235 & 1.85 \\
$2: 5: 1$ & 0.567 & 1.81 & 0.796 & 1.68 \\
\hline \multicolumn{5}{c}{ C. pavonana } \\
\hline $1: 5: 1$ & 0.588 & 1.15 & 0.756 & 0.47 \\
$2: 5: 1$ & 0.366 & 0.86 & 0.792 & 0.45 \\
\hline
\end{tabular}

${ }^{a}$ Expected $\mathrm{LC}_{\mathrm{x}}$ and co-toxicity ratio at $\mathrm{LC}_{\mathrm{x}}$ were calculated according to Robertson \& Smith (1984) as described in Materials and Methods. 
activity with $\mathrm{LC}_{95}$ of about 3\%. Prijono (1999) proposed that a plant extract was considered to have strong insecticidal activity if it could give at least $80 \%$ insect mortality at concentrations of less than $0.5 \%$. Based on this criteria, only at the concentration ratio of 2:5:1 that the mixture of $\mathrm{Pa}, \mathrm{Sr}$ and $\mathrm{Tv}$ extract had strong insecticidal activity against DBM (Table 1). Like against DBM, Pa and Tv extracts had strong insecticidal activity against $\mathrm{CHC}$ and $\mathrm{Sr}$ extract indicated rather weak activity. Moreover, only $\mathrm{Pa}, \mathrm{Sr}$, and $\mathrm{Tv}$ extract mixture at a concentration ratio of $2: 5: 1$ that had strong insecticidal activity against $\mathrm{CHC}$ (Table 2). Single Tv and $\mathrm{Pr}$ extracts as well as the mixed extract of $\mathrm{Pr}, \mathrm{Sr}$ and $\mathrm{TV}$ at a concentration ratio of 1:5:2 had strong insecticidal activity against $\mathrm{CHC}$ (Table 3 ).

The strong insecticidal activity of single $\mathrm{Pa}$ and Tv extracts against DBM and $\mathrm{CHC}$ as well as that of Pr extract against $\mathrm{CHC}$ were in agreement with previous reports (Zarkani et al., 2009; Zarkani et al., 2010; Chenta \& Prijono, 2014; Nailufar \& Prijono, 2017; Prijono et al., 2020). Pr extract had also been reported to have a good contact effect against some sucking pests including papaya mealybug Paracoccus marginatus (Asnan et al., 2015), tea mosquito bug Helopeltis antonii (Indriati et al., 2015; Rohimatun et al., 2020b), and rice brown planthopper Nilaparvata lugens (Nuryanti et al., 2018b). Furthermore, the following binary extract mixtures had been reported to be synergistic against CHC: $P$. aduncum $+S$. rarak (Syahroni \& Prijono, 2013), P. aduncum + T. vogelii (Nurfajrina \& Prijono, 2015; Nailufar \& Prijono, 2017), P. retrofractum + T. vogelii (Nurfajrina \& Prijono, 2015; Prijono et al., 2020), and T. vogelii + S. rarak (Irawan, 2012). Recently, Rohimatun et al. (2020a) reported that extract mixtures of $P$. retrofractum and Curcuma xanthorrhiza at concentration ratios of 4:1, 2:1, 1:1, $1: 2$, and $1: 4$ were synergistic against $H$. antonii.

The strong insecticidal activity of $\mathrm{Pa}$ fruit extract was mainly attributable to the presence of a phenylpropanoid/lignan compound, dillapiole (Bernard et al., 1995; Hasyim, 2011). At the cellular level, dillapiole inhibited the activity of cytochrome P450 enzymes in breaking down toxic compounds in living cells resulting in the accumulation of those toxic compounds in the body which might eventually lead to insect death (Bernard et al., 1995).

The main active compounds responsible for the insecticidal activity of Tv leaf extract belong to the rotenoids, especially deguelin, tephrosin, and rotenone (Delfel et al., 1970; Stevenson et al., 2012). Rotenone is a stomach and contact poison against various insect pests (Yu, 2015). It is a cellular respiration poison that acts by inhibiting electron transfer in Complex I of the electron transport chain in the mitochondria (Hollingworth, 2001). This causes the reduction of ATP production leading to depletion of the cellular energy source.

The principal insecticidal compounds in Pr fruit extract belong to piperamide compounds, including piperine, piperlonguminine, guineensine, pipericides, and retrofractamide A (Kikuzaki et al., 1993; Parmar et al., 1997). Piperamide compounds which have a methylenedioxyphenyl (MDP) moiety in their chemical structure, including those five compounds, exhibit dual action as neurotoxicants and metabolic poisons (Miyakado et al., 1989; Scott et al., 2008). Like dillapiole, piperamides possessing an MDP moiety can inhibit the detoxification function of cytochrome P450 (Scott et al., 2008).

The main chemical substances in $S$. rarak fruits are saponins (Morikawa et al., 2009). Methanolic and aqueous $S$. rarak fruit extracts were reported to have moderate insecticidal activity against CHC (Syahroni $\&$ Prijono, 2013). Saponins could disrupt cell membrane integrity and damage the mucous lining of insect digestive system cells (Francis et al., 2002; Qasim et al., 2020).

The synergistic action of the test extract mixtures might be contributed by MDP-possessing compounds, such as dillapiole in $P$. aduncum and piperamides in $P$. retrofractum extract, which inhibited the activity of cytochrome P450 detoxification enzymes (Bernard et al., 1995; Scott et al., 2008). Inhibition of cytochrome

Table 5. Joint effect of $P$. retrofractum $(\mathrm{Pr}), S$. rarak $(\mathrm{Sr})$ and $T$. vogelii $(\mathrm{Tv})$ extract mixtures on C. pavonana larvae at $96 \mathrm{~h}$ after treatment

\begin{tabular}{ccccc}
\hline $\begin{array}{c}\text { Concentration ratio of } \\
\text { Pr, Sr and Tv extract }\end{array}$ & $\begin{array}{c}\text { Expected } \\
\mathrm{LC}_{50}{ }^{\mathrm{a}}(\%)\end{array}$ & $\begin{array}{c}\text { Co-toxicity } \\
\text { ratio at } \mathrm{LC}_{50}{ }^{\mathrm{a}}\end{array}$ & $\begin{array}{c}\text { Expected } \\
\mathrm{LC}_{95}{ }^{\mathrm{a}}(\%)\end{array}$ & $\begin{array}{c}\text { Co-toxicity } \\
\text { ratio at } \mathrm{LC}_{95}{ }^{\mathrm{a}}\end{array}$ \\
\hline $1: 5: 1$ & 0.424 & 1.94 & 1.127 & 1.13 \\
$1: 5: 2$ & 0.244 & 1.43 & 0.854 & 1.88 \\
$2: 5: 1$ & 0.417 & 1.92 & 0.867 & 1.44 \\
\hline
\end{tabular}

${ }^{a}$ Expected $\mathrm{LC}_{\mathrm{x}}$ and co-toxicity ratio at $\mathrm{LC}_{\mathrm{x}}$ were calculated according to Robertson $\&$ Smith (1984) as described in Materials and Methods. 
P450 by those compounds might retain the action of active compounds in other extracts so as to impart synergistic action of the test extract mixtures. Furthermore, disruption of cell membrane integrity by saponins in $S$. rarak extract might facilitate the entry of active compounds of other extracts in the mixtures through the insect midgut wall and this process might also contribute to the synergistic action of the test extract mixtures.

A probable explanation for the antagonistic action of $\mathrm{Pa}, \mathrm{Sr}$ and $\mathrm{Tv}$ extract mixtures at the 1:5:1 $\left(\mathrm{LC}_{95}\right.$ level) and 1:5:2 ratio ( $\mathrm{LC}_{50}$ and $\mathrm{LC}_{95}$ level) against $\mathrm{CHC}$ was that the proportion of $\mathrm{Pa}$ extract relative to $\mathrm{TV}$ extract in those mixtures was not sufficient to provide appropriate amounts of compounds that were needed to proportionately inhibit toxin detoxifying enzymes in the insect body. The proportion of $\mathrm{Pa}$ extract relative to $\mathrm{Tv}$ extract in the $\mathrm{Pa}, \mathrm{Sr}$ and $\mathrm{Tv}$ extract mixtures at the $1: 5: 1$ and $1: 5: 2$ ratios was lower than that in the synergistic 2:5:1 mixture. Nailufar \& Prijono (2017) reported that in $\mathrm{Pa}$ and $\mathrm{Tv}$ extract mixtures, the higher the proportion of $\mathrm{Pa}$ extract relative to Tv extract, the stronger their synergistic activity.

Most plant extract mixtures studied so far containing extracts from two different plant species or binary mixtures. In this study, extracts from three different plant species (ternary mixtures) were combined. Active constituents of each extract in the ternary extract mixtures tested have different modes of action (Hollingworth, 2001; Scott et al. 2008; Qasim et al., 2020). Thus, ternary extract mixtures containing compounds with more than two different modes of action are expected to exert more multiple attacks on their target sites than binary extract mixtures. Moreover, these actions could be potentiated by different synergism mechanisms as described above.

Four plant species used in this study could grow well in many parts of Indonesia (Sunarno, 1997; Jansen, 1999; Utami \& Jansen, 1999; Widowati, 2003). For mass-production of botanical insecticides, the source plants could be cultivated in a selected suitable location around the production site. The use of synergistic plant extract mixtures constitutes one of the attempts to enhance the performance of botanical insecticides. A further enhancement of the botanical insecticide performance might be achieved through the application of recent development in insecticide formulation technologies including nanotechnology (Gahukar \& Das, 2020). Nuryanti et al. (2018a) reported that a nanoemulsion formulation of $P$. retrofractum and
Tagetes erecta extract mixtures showed a strong insecticidal activity against $N$. lugens $\left(\mathrm{LC}_{95} 0.15 \%\right)$.

The use of extract mixtures offers some advantages over single extracts (Nailufar \& Prijono, 2017). It might increase the spectrum of activity of extract mixtures against target pests. A lower concentration is needed to achieve a certain level of control if the extract mixture was synergistic. Further, lower extract application rates might minimize the risk of poisoning non-target organisms and the environment in general. Application of synergistic botanical insecticides at lower rates may reduce application costs. The use of synergistic extract mixtures could delay the development of insecticide resistance in target pests, if any. Moreover, the use of mixed extracts would harness better the existing rich botanical diversity and as such would reduce the dependence on a single plant species as sources of botanical insecticides (Isman, 2006).

\section{CONCLUSION}

Mixtures of $P$. aduncum fruit, S. rarak fruit, and T. vogelii leaf extract at appropriate proportions were synergistic against $P$. xylostella and $C$. pavonana larvae. $P$. retrofractum fruit, $S$. rarak fruit, and $T$. vogelii leaf extract mixtures at proper proportions were also synergistic against $C$. pavonana larvae. Those synergistic extract mixtures are potential alternatives for the control of $P$. xylostella and C. pavonana.

\section{ACKNOWLEDGMENT}

The authors thank the Field Manager of Teaching Farm of the Faculty of Agriculture, Bogor Agricultural University at Pacet District, Cianjur Regency, West Java, for supplying broccoli seedlings. The technical assistance of Egi Rahmawan was rightly appreciated.

\section{REFERENCES}

Abizar M \& Prijono D. 2010. Aktivitas insektisida ekstrak daun dan biji Tephrosia vogelii J.D. Hooker (Leguminosae) dan ekstrak buah Piper cubeba L. (Piperaceae) terhadap larva Crocidolomia pavonana (F.) (Lepidoptera: Crambidae). J. HPT Tropika. 10(1): 1-12.

Aktar MW, Sengupta D, \& Chowdhury A. 2009. Impact of pesticides use in agriculture: their benefits and hazards. Interdisc. Toxicol. 2(1): 1-12. 
Asnan TAW, Sartiami D, Anwar R, \& Dadang. 2015. Keefektifan ekstrak Piper retrofractum Vahl., Anonna squamosa L. dan Tephrosia vogelii Hook. serta campurannya terhadap imago kutu putih pepaya Paracoccus marginatus Williams \& Granara de Willink (Hemiptera: Pseudococcidae). JEI. 12(2): 80-90.

Bernard CB, Krishanmurty HG, Chauret D, Durst T, Philogène BJ, Sánchez-Vindas $\mathrm{P}$, Hasbun $\mathrm{C}$, Poveda L, San Román L, \& Arnason JT. 1995. Insecticidal defenses of Piperaceae from the neotropics. J. Chem. Ecol. 21(6): 801-814.

Chenta WEL \& Prijono D. 2014. Kerentanan Plutella xylostella dari Kejajar Dieng, Kabupaten Wonosobo, Jawa Tengah terhadap lima jenis insektisida komersial dan ekstrak buah Piper aduncum. In: Ivayani, Sanjaya P, Lestari P, Rusita, Yelly F, Rosanti N, Riyanti RR \& Tedy R (Eds.). Prosiding Seminar Nasional dan Rapat Tahunan Dekan Bidang Ilmu Pertanian, BKSPTN Wilayah Barat 2014. pp. 673-679. Fakultas Pertanian, Universitas Lampung, Bandar Lampung.

Chou TC \& Talalay P. 1984. Quantitative analysis of dose-effect relationships: the combined effects of multiple drugs or enzyme inhibitors. $A d v$. Enzym Regul. 22: 27-55.

Delfel NE, Tallent WH, Carlson DG, \& Wolff IA. 1970. Distribution of rotenone and deguelin in Tephrosia vogelii and separation of rotenoid-rich fractions. J. Agric. Food Chem. 18(3): 385-390.

Durairaj C, Sambathkumar S, \& Mohankumar S. 2016. Integrated pest management of cruciferous vegetables. In: Muniappan R \& Heinrichs EA (Eds.). Integrated Pest Management of Tropical Vegetable Crops. pp. 149-165. Springer, Dordrecht.

Francis G, Kerem Z, Makkar HPS, \& Becker K. 2002. The biological action of saponins in animal systems: a review. Br. J. Nutr. 88(6): 587-605.

Furlong MJ, Wright DJ, \& Dosdall LM. 2013. Diamondback moth ecology and management: problems, progress, and prospects. Annu. Rev. Entomol. 58: 517-541.

Gahukar RT \& Das RK. 2020. Plant-derived nanopesticides for agricultural pest control: challenges and prospects. Nanotechnol. Environ. Eng. 5(3): 1-9.
Grzywacz D, Rossbach A, Rauf A, Russell DA, Srinivasan R, \& Shelton AM. 2010. Current control methods for diamondback moth and other brassica insect pests and the prospects for improved management with lepidopteran-resistant Bt vegetable brassicas in Asia and Africa. Crop Prot. 29(1): 68-79.

Hasyim DM. 2011. Potensi buah sirih hutan (Piper aduncum) sebagai insektisida botani terhadap larva Crocidolomia pavonana. Tesis. Institut Pertanian Bogor, Bogor.

Hollingworth RM. 2001. Inhibitors and uncouplers of mitochondrial oxidative phosphorylation. In: Krieger R, Doull J, Ecobichon D, Gammon D, Hodgson E, Reiter L, \& Ross J (Eds.). Handbook of Pesticide Toxicology, Vol. 2: Agents. pp. 1169-1261. Academic Press, San Diego.

Houghton PJ \& Raman A. 1998. Laboratory Handbook for the Fractionation of Natural Extracts. Chapman \& Hall, London.

Indriati G, Dadang, \& Prijono D. 2015. Aktivitas insektisida ekstrak buah cabai jawa (Piper retrofractum) terhadap Helopeltis antonii (Hemiptera: Miridae). J. Littri. 21(1): 33-40.

Irawan R. 2012. Toksisitas campuran ekstrak daun Tephrosia vogelii (Leguminosae) dan buah Sapindus rarak (Sapindaceae) terhadap larva Crocidolomia pavonana. Skripsi. Institut Pertanian Bogor, Bogor.

Isman MB. 2006. Botanical insecticides, deterrents, and repellents in modern agriculture and an increasingly regulated world. Annu. Rev. Entomol. 51: 45-66.

Jansen PCM. 1999. Piper aduncum L. In: de Guzman CC \& Siemonsma JS (Eds.). Plant Resources of South-East Asia No. 13: Spices. p. 260. PROSEA Foundation, Bogor.

Kikuzaki H, Kawabata M, Ishida E, Akazawa Y, Takei Y, \& Nakatani N. 1993. LC-MS analysis and structural determination of new amides from Javanese long pepper (Piper retrofractum). Biosci. Biotechnol. Biochem. 57(8): 1329-1333.

Mediana G \& Prijono D. 2014. Pengaruh pemanasan dan penyimpanan terhadap aktivitas insektisida ekstrak lerak (Sapindus rarak) pada larva 
Crocidolomia pavonana (F.) (Lepidoptera: Crambidae). Agrovigor 7(2): 90-98.

Miyakado M, Nakayama I, \& Ohno N. 1989. Insecticidal unsaturated isobutylamides. In: Arnason JT, Philogene BJR, \& Morand P (Eds.). Insecticides of Plant Origin. pp. 173-187. American Chemical Society, Washington, D.C.

Morikawa T, Xie Y, Asao Y, Okamoto M, Yamashita C, Muraoka O, Matsuda H, Pongpiriyadacha Y, Yuan D, \& Yoshikawa M. 2009. Oleanane-type triterpene oligoglycosides with pancreatic lipase inhibitory activity from the pericarps of Sapindus rarak. Phytochemistry. 70(9): 1166-1172.

Nailufar N \& Prijono D. 2017. Synergistic activity of Piper aduncum fruit and Tephrosia vogelii leaf extracts against the cabbage head caterpillar, Crocidolomia pavonana. J. ISSAAS. 23(1): 102-110.

Nurfajrina A \& Prijono D. 2015. Keefektifan ekstrak lima spesies Piper (Piperaceae) untuk meningkatkan toksisitas ekstrak Tephrosia vogelii terhadap hama kubis Crocidolomia pavonana. In: Mubin N, Pradana MG, Suryadi, Nurjayadi MY, \& Sukaryana D (Eds.). Prosiding Seminar Nasional Perlindungan Tanaman II. pp. 88-96. Pusat Kajian Pengendalian Hama Terpadu, Institut Pertanian Bogor, Bogor.

Nuryanti NSP, Martono E, Ratna ES, \& Dadang. 2018a. Characteristics and toxicity of nanoemulsion formulation of Piper retrofractum and Tagetes erecta extract mixtures. J. HPT Tropika. 18(1): $1-11$.

Nuryanti NSP, Martono E, Ratna ES, \& Dadang. 2018 b. The bioactivities of selected Piperaceae and Asteraceae plant extracts against brown planthopper (Nilaparvata lugens Stål.). J. ISSAAS. 24(2): 70-78.

Parmar VS, Jain SC, Bisht KS, Jain R, Taneja P, Jha A, Tyagi OD, Prasad AK, Wengel J, Olsen CE, \& Boll PM. 1997. Phytochemistry of the genus Piper. Phytochemistry. 46(4): 597-673.

Philips CR, Fu Z, Kuhar TP, Shelton AM, \& Cordero RJ. 2014. Natural history, ecology, and management of diamondback moth (Lepidoptera: Plutellidae), with emphasis on the United States. J. Integr. Pest Manag. 5(3): D1-D11.
Prijono D. 1999. Prospek dan strategi pemanfaatan insektisida alami dalam PHT. In: Nugroho BW, Dadang, \& Prijono D (Eds.). Bahan Pelatihan Pengembangan dan Pemanfataan Insektisida Alami. pp. 1-7. Pusat Kajian Pengendalian Hama Terpadu IPB.

Prijono D \& Hassan E. 1992. Life cycle and demography of Crocidolomia binotalis Zeller (Lepidoptera: Pyralidae) on broccoli in the laboratory. Indon. J. Trop. Agric. 4(1): 18-24.

Prijono D, Pusparini AM, Aini HA, \& Munawaroh. 2019. Susceptibility of the diamondback moth, Plutella xylostella (L.), from West Java, Indonesia to fivenon-classical insecticides. Int. J. Agric. Environ. Biores. 4(1): 51-60.

Prijono D, Wulan RDR, Ferdi, \& Saryanah NA. 2020. Insecticidal activity of the extracts of Piper retrofractum fruit and Tephrosia vogelii leaf and their mixtures against Crocidolomia pavonana. Cropsaver 3(2): 68-75.

Qasim M, Islam W, Ashraf HJ, Ali I, \& Wang L. 2020. Saponins in insect pest control. In: Mérillon JM \& Ramawat KG (Eds.). Co-Evolution of Secondary Metabolites. pp. 897-924. Springer Nature, Cham, Switzerland.

Rauf A, Prijono D, Dadang, Winasa IW, \& Russell DA. 2004. Survey of pest control practices of cabbage farmers in West Java, Indonesia. Cabbage Pest Control Survey Report.

Robertson JL \& Smith KC. 1984. Joint action of pyrethroids with organophosphorus and carbamate insecticides applied to western spruce budworm (Lepidoptera: Tortricidae). J. Econ. Entomol. 77(1): 16-22.

Robertson JL, Preisler HK, \& Russell RM. 2003. PoloPlus: Probit and Logit Analysis, User's Guide. LeOra Software, Petaluma, CA.

Rohimatun, Dadang, Winasa IW, \& Yuliani S. 2020a. Kompatibilitas ekstrak Piper retrofractrum Vahl. dan Curcuma xanthorrhiza Roxb. untuk pengendalian Helopeltis antonii Sign. Bul. Littro. 31(2): 107-122.

Rohimatun, Yuliani S, Winasa IW, \& Dadang. 2020b. Efficacy of selected Piperaceae, Asteraceae, and Zingiberaceae plant extracts against Helopeltis antonii Sign. J. ISSAAS. 26(2): 145-157. 
Sarfraz M, Keddie AB, \& Dosdall LM. 2005. Biological control of the diamondback moth, Plutella xylostella: a review. Biocontrol Sci. Technol. 15(8): 763-789.

Sastrosiswojo S \& Sastrodihardjo S. 1986. Status of biological control of diamondback moth by introduced parasitoid, Diadegma eucerophaga in Indonesia. In: Talekar NS \& Griggs TD (Eds.). Diamondback Moth Management, Proceedings of the First International Workshop. pp. 185-194. AVRDC, Shanhua.

Sastrosiswojo S \& Setiawati W. 1992. Biology and control of Crocidolomia binotalis in Indonesia. In: Talekar NS (Ed.). Diamondback Moth and Other Crucifer Pests, Proceedings of the Second International Workshop. pp. 81-87. AVRDC, Shanhua.

Sastrosiswojo S \& Setiawati W. 1993. Hama-hama tanaman kubis dan cara pengendaliannya. In: Permadi AH \& Sastrosiswojo S (Eds.). Kubis. pp. 39-50. Balai Penelitian Hortikultura, Lembang-Bandung.

Scott IM, Jensen HR, Philogène BJR, \& Arnason JT. 2008. A review of Piper spp. (Piperaceae) phytochemistry, insecticidal activity and mode of action. Phytochem. Rev. 7: 65-75.

Shepard BM, Hammig MD, Carner GR, Ooi PAC, Smith JP, Dilts R, \& Rauf A. 2009. Implementing integrated pest management in developing and developed countries. In: Peshin R \& Dhawan AK (Eds.). Integrated Pest Management: Dissemination and Impact. pp. 275-305. Springer, Dordrecht.

Stevenson PC, Kite GC, Lewis GP, Forest F, Nyirenda SP, Belmain SR, Sileshi GW, \& Veitch NC. 2012. Distinct chemotypes of Tephrosia vogelii and implications for their use in pest control and soil enrichment. Phytochemistry. 78: 135-146.

Sunarno B. 1997. Tephrosia vogelii J.D. Hooker. In: Hanum IF \& van der Maesen LJG (Eds.). Plant Resources of South-East Asia No. 11: Auxiliary
Plants. pp. 248-251. PROSEA Foundation, Bogor.

Syahroni YY \& Prijono D. 2013. Aktivitas insektisida ekstrak buah Piper aduncum L. (Piperaceae) dan Sapindus rarak DC. (Sapindaceae) serta campurannya terhadap larva Crocidolomia pavonana (F.) (Lepidoptera: Crambidae). J. Entomol. Indones. 10(1): 39-50.

Utami D \& Jansen PCM. 1999. Piper L. In: de Guzman CC \& Siemonsma JS (Eds.). Plant Resources of South-East Asia No. 13: Spices. pp. 183188. PROSEA Foundation, Bogor.

Widowati L. 2003. Sapindus rarak DC. In: Lemmens RHMJ \& Bunyapraphastsara N (Eds.). Plant Resources of South-East Asia Vol 12(3). Medicinal and Poisonous Plants. pp. 358359. PROSEA Foundation, Bogor.

Wyckhuys KAG, Aebi A, van Lexmond MFIJB, Bojaca CR, Bonmatin JM, Furlan L, Guerrero JA, Mai TV, Pham HV, Sanchez-Bayo F, \& Ikenaka Y. 2020. Resolving the twin human and environmental health hazards of a plant-based diet. Environ. Int. 144: 106081.

Yu SJ. 2015. The Toxicology and Biochemistry of Insecticides, 2nd ed. CRC Press, Boca Raton, FL.

Zarkani A, Prijono D, \& Pudjianto. 2009. Pengujian ekstrak Piper retrofractum sebagai insektisida nabati terhadap Crocidolomia pavonana dan Plutella xylostella serta keamanannya terhadap Diadegma semiclausum. J. Akta Agrosia. 12(1): 35-44.

Zarkani A, Prijono D, \& Pudjianto. 2010. Efikasi insektisida nabati ekstrak daun Tephrosia vogelii Hook. terhadap Crocidolomia pavonana (F.) dan Plutella xylostella (L.) serta pengaruhnya pada Diadegma semiclausum (Hellen). JIPI. 12(1): 68-75. 